\title{
建筑机电设备安装工程的施工控制实例研究
}

Case study of Construction Control of the Installation Engieering of Building Mechanilal and

\section{Electrical Equipment}

\author{
张瑛 \\ Ying Zhang \\ 上海倍安实业有限公司, 中国・上海 200000 \\ Shanghai Beian Industrial Co.Ltd., Shanghai, 200000, China
}

\begin{abstract}
【摘要】随着当前建筑物高度的不断提升, 中国建筑工程需要安装对应的建筑机电设备。但是在建筑机电设备的安装过程中, 需要考虑的安装 管理因素较多。只有明确安装管理控制要点, 才能及时地控制好施工管理因素,进而保障最终的施工管理质量。论文结合项目实例, 详细论述了建 筑机电设备安装工程施工控制的要点, 研究成果可为相关研究与应用提供参考。
\end{abstract}

【Abstract】With the continuous improvement of the building height, China's construction projects need to install the corresponding building mechanical and electrical equipment. However, in the process of installing building machanical and electrical equipment, there are many factors to be considered for installation management. Only when the key points of installation management are clear, can the construction management factors be controlled in time, so as to ensure the final quality of the construction management. Combined with the project example, this paper detailedly discusses the main points of construction control for the installation engineering of building mechanical and electrical equipment. The research results can provide reference for related research and application.

【关键词】建筑;机电设备;安装工程;施工要点;控制分析

【Keywords \building; electromechanical equipment; installation engineering; keypoints of construction; control analysis 【DOI】http://dx.doi.org/10.26549/gcjsygl.v2i4.763

\section{1 引言}

在进行建筑机电设备安装过程中，由于对应的设备安装 管理因素控制较多, 需要对机电设备安装管理中的控制因素 进行专门的分析, 通过施工管理要点的控制提升建筑机电设 备的安装质量。

\section{2 建筑机电设备安装工程的施工准备工作}

\section{1 做好施工设计图纸}

在进行建筑机电设备安装工程施工管理运行之前, 应该 针对建筑工程机电设备安装中的图纸设计进行专门的规划, 保障在前期的施工设计图纸规划中，能够将对应的施工管理 因素控制好。将施工设计图纸进行规划设计是保障整体施工 管理质量提升的关键性因素 ${ }^{[1]}$ 。除此之外,在施工设计图纸的 规划中，还应该将机电设备安装运行中的管理材料及对应的
规格都准备好,以便于后续施工管理工作的开展 ${ }^{[2]}$ 。

\section{2 合理选择机电设备}

机电设备是整个建筑机电设备安装中的重要性安装元 素, 只有保障对机电设备的选择科学合理, 才能提升对应的施 工管理控制能力, 将对应的施工管理质量提升上来。因此,在 进行建筑施工管理因素的控制过程中, 应该对机电设备的选 择进行科学的分析。

鉴于目前中国建筑机电设备市场运行中的机电设备种类 较多, 而国家对于建筑机电设备安装运行管理的质量并没有 统一的标准, 因此, 在这种背景下的安装工程施工管理设备选 择过程中, 对应的施工设备管理者应该本着安全性施工管理 控制原则, 将机电设备的选择以保障建筑工程运行安全为选 择的前提, 这样才能在建筑工程机电设备的选择中处理好对 应的设备选择问题 ${ }^{[3 \mid}$ 
例如, 相关的设备选择人员, 在进行设备的选择过程中, 应该充分地分析每一种机电设备的性能及质量, 然后按照具 体的施工管理工作开展需求,去选择安全性能较高,市场评价 较好的机电设备应用到建筑工程施工安装管理中。见图 1 机 电设备选择流程图。

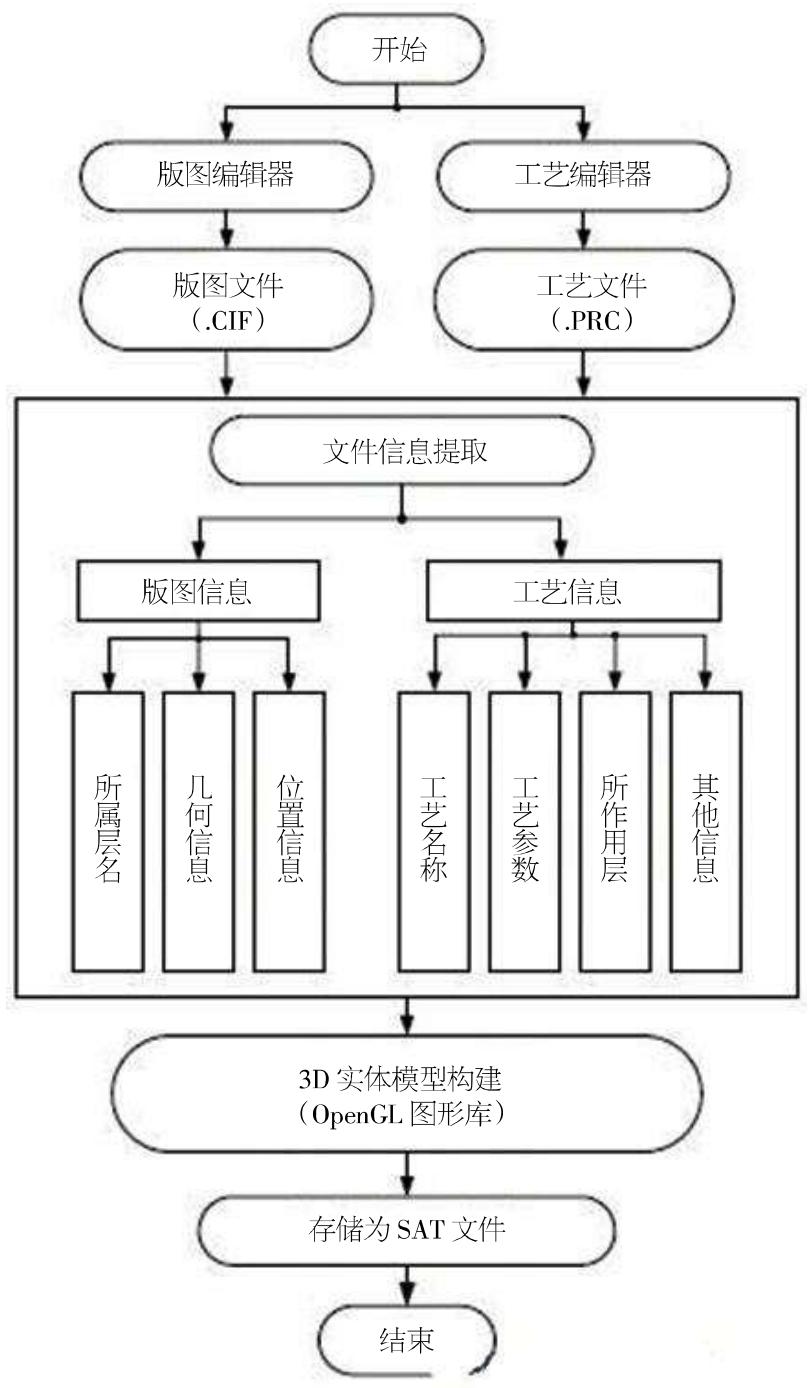

图 1 机电设备选择流程

\section{3 建筑机电设备安装工程施工要点分析}

\section{1 机电设备安装噪音处理}

在进行建筑机电设备安装管理控制中, 噪音管理是保障 机电设备安装运行控制的重要前提。只有保障了机电设备安 装中的噪音管理, 才能够在后续的施工管理中及时地将对应 的施工管理控制要点协调好。

(1)首先, 在进行建筑机电设备安装施工管理中, 应该对机 房的布局进行科学的规划, 保障机房的布局能够达到最优 ${ }^{[4]}$ 并且在进行建筑机电设备安装中的机房施工中，选择具有隔 震和抗噪音的部件,降低设备运行中的噪音。
(2)其次,对于机电设备安装施工中的支架管理,应该注 重对机电设备安装中的支架隔音处理，降低支架的噪音, 减 少污染。

因此,在这种背景下,应该针对建筑施工管理中的支架进 行均衡性施工处理, 确保在其施工均衡性处理中, 能够将对应 的施工管理因素及施工管理要点控制好。

\section{2 管线施工管理要点控制}

建筑机电设备安装工程施工管理中，对于管线施工管理 是必不可少的, 只有保障在建筑工程施工管理中, 能够将对应 的管线施工管理要点控制好，才能提升整体的建筑机电设备 安装管理质量。因此, 应该从以下几点因素进行分析:

(1)对于管线的安装，应该将其在预埋剪力墙内进行孔洞 处理,安装线槽。

(2)将管线桥架安装好, 保障在管线桥架安装过程中, 能够 将对应的管线安装管理要点控制好。

(3)针对管线施工管理中的铺设管理要点控制, 在进行管 线的施工管理中,应该针对施工管理中的管线铺设进行分析, 借助管线铺设将对应的施工控制要点处理好[1]。

\section{3 电气设备施工管理控制}

电气设备是建筑机电设备安装工程施工管理中需要重点 控制的一项管理因素，对于施工管理中的电器开关应该进行 及时的更换, 这样才能使电气设备的安装运行能够得到保障。

作为建筑机电设备安装工程施工管理者, 在进行对应的 施工管理因素控制中, 应该及时对电气设备进行状态检查, 包 括对设备的断路器安装情况, 以及电流互感元件的安装处理 等进行专门的分析。

如果不能处理好该环节施工管理中的因素控制，就会造 成机电设备安装中出现较为严重的设备安装运行故障, 对于 机电设备的安装是很不利的。所以在该环节的施工管理控制 中, 对应的施工管理人员, 应及时针对施工管理中的电气设备 施工控制进行分析, 细化该环节施工管理中的控制要点。

\section{4 接地线施工管理控制}

接地线施工管理也是建筑机电设备安装工程施工管理中 需要控制好的一项施工管理控制因素, 在机电设备安装管理 控制中, 应该确定对应的接地线安装种类,并且能够明确接地 线安装失误带来的危害，这样才能及时地将对应的施工安装 管理因素控制好。

例如,在进行施工要点控制中,应该针对金属元件和非金 属元件的安装进行分析,并且在分析中, 将对应的施工管理要 点控制协调好, 保障在控制协调中, 能够将对应的控制管理要 点处理好。将接电线安装控制处理好, 能够降低设备运行安装 中事故出现的概率,对于整体的施工质量提升而言, 具有重要 
性研究意义[门]。

\section{5 系统调式施工控制要点}

系统调试是建筑机电设备安装管理控制中的最后一项施 工安装管理控制因素,当施工管理者,按照前期的施工图纸规 划,将对应的施工管理因素控制好之后。对应的设备安装管理 人员,应该及时对设备的系统运行进行调试。

进行建筑机电设备安装系统调试的目的就是保证建筑机 电设备安装管理中的线路安装工作以及对应的线路组装正 确。并且在进行系统调试工作的处理中, 需要明确系统安装是 否满足预期的安装规划效果。只有通过系统调试才能实现建 筑机电设备安装运行控制能力的提升 ${ }^{[81}$ 。见图 2 建筑机电设备 系统调试流程图。
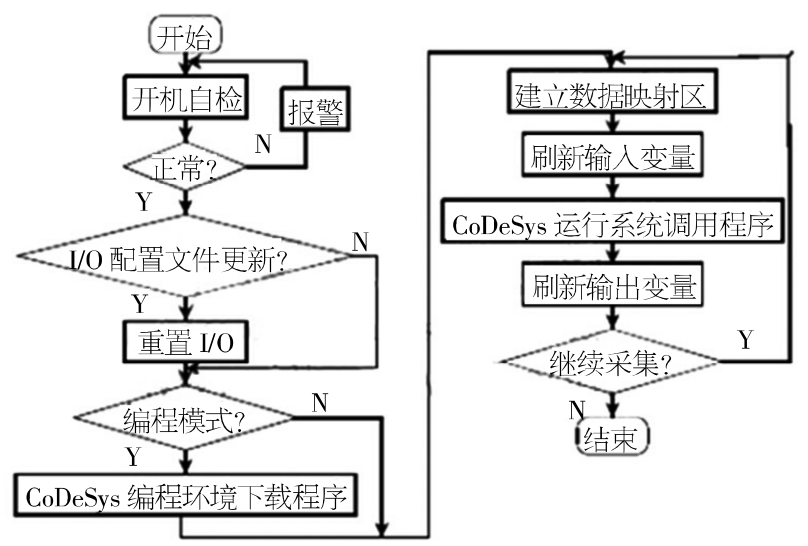

图 2 建筑机电设备系统调试流程

\section{4 建筑机电设备安装工程施工要点控制}

\section{案例分析}

\section{1 厦门市公路局道路研发中心工程}

4.1.1 项目简介

在厦门市公路局道路研发中心工程项目施工建设管理 中, 其对应的项目建设为配套高档写字楼建设, 整个建筑区域 面积 $33270 \mathrm{~m}^{2}$, 其中地下室 1 层, 上部 22 层, 总投资为 9761 万 元。此次施工管理中,共涉及排水工程、电气工程、地下室通风 工程、消防工程以及配电室和水原房等 9 处工程施工建设管 理建设工程。

\section{1 .2 工程项目控制要点}

笔者作为建筑工程项目参与者, 在进行建筑机电设备安 装管理中, 担任建筑设备安装监理工程师, 负责该项目机电 安装的管理。在进行建筑机电设备工程安装施工管理中, 及 时将施工管理中的控制要点进行分析, 主要控制施工管理要 点为智能楼宇设备安装控制中的电力分配管理,智能设备安 装中的空调 VRV 安装控制等, 通过该控制管理因素的实施, 将对应的施工控制要点进行明确。具体的施工控制要点如表 1 所示:
表 1 厦门市公路局道路研发中心工程施工要点控制

\begin{tabular}{c|c}
\hline 编号 & 控制要点 \\
\hline 1 & 智能设备安装系统控制(空调系统 VRV、电路接线系统) \\
2 & 线路接线控制管理(接线管理、地线管理) \\
3 & 管线架设(线路铺设) \\
4 & 设备运行管理(系统调试) \\
\hline
\end{tabular}

\section{2 厦门大嶝对台小额商品交易市场扩建工程}

4.2.1 项目工程简介

厦门大嶝对台小额商品交易市场扩建工程为对应商品交 易市场拓建工程二期, 此次施工建设管理为拓展式建设施工, 地下室一层, 地上五栋四层, 建筑区域总面积 $59360 \mathrm{~m}^{2}$, 共投资 1.1 亿元。

4.2.2 工程项目控制要点

笔者作为此次建筑工程机电设备安装施工主持者, 在针 对机电设备安装管理中, 特别进行了施工管理中的控制要点 管理分析, 并且在施工管理控制中, 担任建筑设备安装监理工 程师, 负责该项目机电安装的管理。其对应的施工管理控制要 点如表 2 所示:

表 2 厦门大嶝对台小额商品交易市场扩建工程施工要点控制

\begin{tabular}{c|c}
\hline 编号 & 控制要点 \\
\hline 1 & 智能设备控制(滚动式电梯组装) \\
2 & 电感系统控制 \\
3 & 线路架设施工控制 \\
4 & 设备系统总控 \\
\hline
\end{tabular}

\section{3 联发杏林湾一号二期工程}

4.3.1 项目工程简介

联发杏林湾一号二期工程为大型建设住宅工程施工改 建, 此次建筑机电设备安装工程施工管理中, 共有六栋建筑, 其中地下室一层, 地上建筑六栋, 三栋为 26、30、33 层建筑, 其 余三栋为 36、39、39 层建筑, 此次建筑属于超高型住宅建筑施 工。整个建筑工程施工管理区域面积 166662 平方米, 共投资 建设经费 6.0 亿元。

\subsection{2 工程项目控制要点}

笔者作为此次建筑机电设备安装工程施工中的主持者, 针对此次建筑工程施工管理中的各项要点管理工作控制进行 了分析, 并且在控制管理分析中, 及时将对应的施工控制要点 进行了分析。具体的控制施工要点如表 3 所示:

表 3 联发杏林湾一号二期工程施工控制要点

\begin{tabular}{c|c}
\hline 编号 & 控制要点 \\
\hline & \\
1 & 针对超高层三栋建筑实施机电设备大功率体系控制 \\
2 & 针对三冻高层建筑进行了基础性机电设备控制 \\
3 & 系统总控中心设置在小区 2 栋 101 室内 \\
4 & 建筑内部总控室设置在顶层及地下负一层内 \\
& \\
\hline
\end{tabular}




\section{工程技术与管理}

Engineering Technology \& Management

\section{5 结语}

综上所述, 在中国现代化建筑工程的建设和发展中, 通过 机电设备的安装能够提升建筑自身的运行能力。而在建筑机 电设备安装施工管理中, 应该注重对施工管理中的控制要点 进行分析, 这样才能及时将对应的施工安全管理因素控制好。

通过论文的研究和分析, 将建筑机电设备安装工程施工 管理要点控制归纳为设备安装噪音处理、管线施工管理、电气 设备安装管理、接地线施工管理以及系统调试施工管理等。借 助以上五点施工要点控制管理, 能够提升建筑机电设备安装 工程施工管理的控制质量, 对于建筑机电设备安装具有重要 保障作用。

在未来的建筑工程施工设计中, 应该针对建筑工程施工 设计中的机电工程安装进行全面的分析, 进而在施工技术的 应用分析中, 衡量好对应的施工技术应用, 保障建筑工程施工 安装技术应用管理能力提升, 为建筑工程施工技术的提升奠 定基础。

\section{参考文献:}

[1]郭静超,殷彦豹.土木建筑工程和机电设备安装工程施工配合 技术要点探讨 [J].江西建材,2016,25(3):76.

[2]林水滨.建筑机电设备安装施工中的管理要点分析 [J].江西建 材,2016,36(22):278.

[3] 井涛. 建筑机械设备安装工程的施工要点分析[J].科技经济导 刊,2017,26(3):159-161.

[4]关同.建筑机械设备安装工程的施工要点分析 [J].城市建设理 论研究(电子版), 2017,25(18):147-149.

[5]陈永军.建筑机械设备安装工程的施工要点分析[J].中国科技 投资,2017,32(20):111-113.

[6]王志雄.建筑机电设备安装施工中的管理要点分析 [J].建筑工 程技术与设计,2017,22(8):111-112.

[7]耿城. 民用建筑机电设备安装工程管理要点分析 [J].建筑与环 境,2016,22(2):73-74.

[8]贺诚. 民用建筑机电设备安装工程管理要点 [J].商品与质量, 2017,20(20):155-157. 